\title{
Down below as a Complex Preposition
}

\author{
Hide Hirao ${ }^{1}$ \\ ${ }^{1}$ Faculty of Internatinal Liberal Arts, Otemon Gakuin University, Ibaraki, Osaka, Japan \\ Correspondence: Hideo Hirao, Faculty of Internatinal Liberal Arts, Otemon Gakuin University, Ibaraki, Osaka, \\ 567-8502, Japan. Tel: 81-72-641-9620.
}

Received: September 10, 2015

Accepted: October 15, 2016

Online Published: October 20, 2016

doi:10.5430/elr.v5n4p1

URL: http://dx.doi.org/10.5430/elr.v5n4p1

\begin{abstract}
Following Hirao (2014) who empirically demonstrated that the string up above is acting as a complex preposition in present-day English, this article will demonstrate that the string down below is also acting as a complex preposition in present-day English based on the following three reasons:

1. Functional distribution of the string

2. Derivational use as a prepositional adverb

3. Adverbial modification of the string

If it is proved that the string is a complex preposition along with the string up above, these two instances would indicate that the grammaticalization process of converting two particles into a complex preposition is a productive word formation process in present-day English.
\end{abstract}

Keywords: Complex preposition, Word formation, Grammaticalization

\section{Introduction}

\subsection{Grammaticalization}

Grammaticalization is a process by which lexical items or constructions come to serve grammatical functions (Hopper and Traugott, 1993, 2003). Recent advances in this theory have also had an impact on the study of complex prepositions. That is, any lexical combinations of lexical items may have a possibility of becoming new complex prepositions. Combinations of lexical items which have never been under the scope of linguistic consideration may have a possiblity of being complex prepositions.

\subsection{Complex Prepositions: Theoritical Review}

Although traditional grammars (e.g. Quirk et. al., 1972, 1985) would take complex prepositions for granted, theoretical arguments on their grammatical significance have not been very active. For instance, Crystal (1980) simply said that sequences like in accordance with are often called complex prepositions. Quirk and Mulholland (1964) might be the first to call attention for the existence of complex prepositions whose structure is "preposition plus (the) noun plus preposition (PNP)", such as in front of and with reference to. Seppänen, Bowen, and Traugott (1994) denied the existence of complex prepositions in English and insisted that they are instances of free forms. Hoffmann (2005), based on a large corpus study, concluded that they are real prepositions. Rompaey and Davidse (2014), in their discussion of historical development of progressive aspect markers (PAM), said that the string, in the middle of, became a complex preposition by reanalysis and the string, in the midest of, became so by analogy before becoming PAMs.

All these araguments centered around the construction PNP. From a radically different perspective, Hirao (2013) demonstrated that lexical items may go through the process of grammaticalization and begin functioning as complex prepositions, based on the examination of three phrasal elements each of which contains and: up and above, down and below, from top to bottom and across. In this article, he indicated that the first two of these may have different versions of complex prepositions without and. Hirao (2014) examined the two-particle string, up above, and concluded that this string is functioning as a complex preposition in present-day English. 


\subsection{Research Question and its Implication}

The present article takes up the two-particle string, down below (the down below string), and examines its uses extensively using corpus data. It is hoped that through this examination the status of the down below string as a complex preposition will be confirmed.

If it is proved that this string is a complex preposition, then we will have witnessed two cases of complex prepositions formed from two words or particles, i.e. up above (which has been confirmed as a complex preposition in Hirao (2014)) and down below. This fact would indicate that the formation of complex prepositions from two particles such as thses is a productive word formation process in English.

\section{Research Method}

Following Hirao (2014), three syntactic aspects of the down below string will be examined:

1. Functional distribution of the string

2. Derivational use as a prepositional adverb

3. Adverbial modification of the string

\subsection{Functional Distribution}

There is a number of syntactic functions that any single word preposition or prepositional phrase headed by the preposition in question may occupy in a sentence. If the down below string occupies the same functions in a sentence, this would strongly indicate that the string is acting as a complex preposition. To check this, examples from the British National Corpus (BNC) as of December 2012 will be examined. All relevant examples in section 3 are from the $\mathrm{BNC}$ and numbered with parentheses.

\subsection{Prepositional Adverb}

Prepositional adverb is a major derivational use of single word prepositions. If the down below string has the same derivational use and has the same scope of usage as prepositional adverbs, it will support the claim that the string is a complex preposition.

\subsection{Adverbial Modification}

It is known that prepositional phrases may be modified at times by adverbs: right at the door, just in time or far beyond the hill. If the down below string or the phrase headed by this string has the same modification pattern, it would suggest that the string is acting as a complex preposition.

\subsection{Productive Word Formation Process}

If, as a result of close scrutiny on the above mentioned syntactic aspects, the down below string is confirmed to be a complex preposition, there would be two confirmed complex prepositions in English: down below and up above (which was confirmed to be a complex preposition in Hirao (2014)). This would suggest that the gramaticalization process of converting two particles into a complex preposition is a productive word formation process in English.

\section{Examination}

In the following sections, various syntactic functions of the down below string will be examined to ensure that the string processes all characteristics of prepositions.

\subsection{Distribution}

Leech and Svartvik (2002) recognized the following four main functions of prepositional phrases with their examples:

\section{Adverbial}

We may need you to do some work in the evening.

2. Modifier in a Noun Phrase

Chelsea felt she had no chance of promotion.

3. Verb Complement

You don't seem particularly worried about the situation.

\section{Adjective Complement}

I'm terribly bad at dates. 
In the following sections, each of these functions will be examined. As has been noted above, the emamples are all from the BNC.

\subsubsection{Adverbial}

The strings headed by down below are often used as place adverbials:

(1) Then she noticed something fluttering down below her.

(2) Looking down below them from the top, they saw that a small crater with the remains of ...

(3) Gazing down below me, I suddenly realized that a huge curtain of mist and rain has swept across the water and was fast obscuring the tundra below.

They are often put at the beginning of the sentences for contrastive or emphatic purpose:

(4) Down below us the river was gleaming.

(5) Down below me there was heavy fighting and I felt very sad.

(6) Down below me the surf thrashed and thundered: the Tonga Trench, a precipitous crack in the ocean floor where two of the planet's great tectonic plates crunched together and were folded downwards to melt again, lay a score of miles away.

They are also used as sentence adverbials:

(7) Down below the bridge, he knew, about eight or nine shambling street people would be setting up the plastic pallets and bakers' trays that would keep them off the floor for the night.

(8) In very open country, the judgement of heights, even down below 200 or $300 \mathrm{feet}$, is surprisingly difficult.

\subsubsection{Modifier in a Noun Phrase}

The strings headed by down below may become nominal modifiers:

(9) Oily waters down below me streaked with rainbow.

(10) If you were right at the top of the tower would the people down below you look like?

(11) And so he climbed to the mountains and there, high in the mountains, in an old stone building lived a man with hair down below his waist.

(12) We had to pick the bind out by hand, er the coal was all er sorted on the screens and er er a u u us lads, we used to stand at the side of the belts that were travelling round and tipping the coal into the wagons down below you see?

\subsubsection{Verb Complement}

These strings may function as complements of verbs. They can function as subject predicates:

(13) When she complained to a doctor that it was down below freezing she could not have been nearer the mark.

(14) Mr Anthony said: 'He really did not appreciate what was down below the bridge.'

(15) Now what we've got here, if you look at the $\mathrm{F} T$ for ten thousand in force policies, we've got a significant jump in January and February at a time when our budget posting was down below budget.

They may be used in inversions:

(16) While they were walking they had not been able to see it, because there were hills in the way; but now they saw that the cottage was really built on a cliff, and down below them was a small bay.

They may serve as complements for other intransitive verbs:

(17) The world price has gone down below that.

(18) The dangerous stinging tentacles hang down below the float.

(19) It was a picture of a girl wearing a frilly bonnet and long, frilly drawers that reached down below her dress to her ankles.

(20) Various panels of brickwork have been left exposed rather than plastered over, and the original heavy timber floor beams generally continue to project down below ceilings.

(21) Very slowly, and keeping down below the seals' horizon, I crept forward towards the sound of singing. 
(22) Because no seismic sources have been detected above sea level in the whole period of observation, we conclude that the fractured region and possibly the intrusion also extend down below sea level.

(23) At a convergent boundary, such as the western coast of South America, two plates are in motion towards each other, with one plate slipping down below the other along a subduction zone.

(24) Yeah, well I mean, that's a, that's a difficult one, inside information, when you get down below the top ranks there are lots of people in the mid mi medium-ranks who would know about insider dealing, and I'm sure use it.

(25) But once you get down below the horizon you get to look round this area here where there's some rope tangled round, some kind of padding, it does tend to get a little bit lost amongst all the pebbles.

In the next example, the string headed by down below is conjoined by another prepositional phrase headed by from, indicating strongly that the string is in fact a complex preposition:

(26) Turn-outs for local elections in Hungary have dropped from 40 to 20 per cent, and in some recent votes down below 15 per cent.

The following examples are complement adverbials for transitive verbs:

(27) 'Take him down below the three flights of hurdles,' Tremayne said, 'then bring him up over them at a useful pace.

(28) I'm the next one I'm gonna do I'm gonna spread it down below nought so we're getting into the negative numbers.

(29) Until at the top of the hill, despite spotting Hermione's black hair and bright red jacket down below her, she came to a stop.

(30) It sold dollars and European currency units for pounds in a determined fashion to counter heavy selling, which briefly pushed the pound down below DM2.95 for the first time since August 1987.

The next is the example of transitive verb complement in a passive sentence:

(31) Copper engraving or etching is not a relief process, but an intaglio one; what is to print black is cut down below the surface, and the copper is wiped before printing.

In the next example, down from beneath and down below are conjoined:

(32) Without further ado she busied herself in pulling her three-quarter-length beige cotton sock down from beneath her trouser leg, and down below her ankle.

\subsubsection{Adjective Complement}

Examples of adjective complements are few but can be found:

(33) Basically what happens is that lava and other material is ejected from a hole in the ground, or crater, which is fed by a single pipe-like supply channel extending deep down below ground.

(34) And she told him wonderful tales, about the sea.king's palace, about the windswept isle of Bujan and the amber stone Alatyr, about Perun, the god of the thunder, about the dragon of Lake Rikavatz and the Zmayevska Vatra, the dragons' fire, which lies deep down below the round of the world.

(35) Yet plunging cliffs, i.e. those whose profiles are continued straight down below the sea, are free from notches, benches and other forms of wave action.

\subsection{Prepositional Adverb}

Prepositional adverb is a major derivational use of prepositions. Instances of down below as an independent adverb can be found in almost all the functions discussed above. Instances of the string as place adverbials are:

(36) It was dark down below, but she could make out the shapes of beer kegs.

(37) Pardon me for being rude it was not me it was my food, it just popped up to say hello, and now it's gone back down below

(38) 'Waiting down below for us, I shouldn't wonder — wanting us to get a move on so 's 'e can keep 'is hand in at 'is old trade!

(39) There's been a bit of a fight down below.

(40) Their families, if they come over too, live down below on the edge of the city in a sort of ghetto. 
(41) The sun was already hot on her face, and down below in the garden two doves stalked the lawn, looking for titbits.

It may be used as a sentence adverbial:

(42) Down below, a green slate floor butts up to and contrasts with the smooth screed concrete on either side.

(43) Down below, they could hear the sounds of the thing shambling on the staircase.

(44) Down below, where they were sitting, the air softened, became almost visible, as if shaded in with charcoal, closer to smoke than air.

The string may be used as a modifier of noun in a noun phrase:

(45) 'Talks funny,' colluded the crew down below.

(46) They were upstairs in Edgar Lloyd, Hattes, when Ben heard voices down below.

(47) The party down below was over.

(48) And when the heavy rain's heavy er it rises you see, well you've got to put more power, switch more power on to the machines down below in the station.

(49) When the chimney is in place keep picking up Wilma, who'll be near the Burger Bar or somewhere down below.

Among verb complements, instances of subject predicates are:

(50) It was down below, lying on the stairs.

(51) 'You'd better check that your cute friend didn't steal anything when he was down below.'

(52) There was another great big box but instead of being up high it was down below and I could easily Mummy have helped myself to it

(53) The band was down below and then a loft, a long wooden just like a dance hall up above and they just did that and they just they had tables set and then they removed them for the dances.

(54) I watch it from my seat in the New York as well, which is down below to the right; I can see the top of its maroon awning.

Instances of complements for other intransitive verbs are:

(55) He touched his forehead in mock humility, and ducked down below.

(56) 'Down below the rocks fall, hear the sound of the dying'.

Instances of adverbial complements of transitive verbs are:

(57) ... put it down below.

(58) By this time I was terrified and I don't ever be so and our teacher took us down below and tried to play games...

(59) Her picture and her silk quilt had been carried down below in the chaos of last night and she did not have the energy to seek them out.

In the following examples, the string itself is a complement of the preposition from. This is an indication that the string has the strong unity of its own:

(60) There was another landing here, and more stairs; there was noise of some kind from down below.

(61) And then, from down below, an enraged roaring swelled up to fill the staircase.

(62) There was silence for a moment as they held each other 's eyes, broken only by the faint sound of dance music from down below.

(63) He believed that he got up and felt his feet sink through the floor while the music from down below came up like vapour and was breathed rather than heard.

\subsection{Adverbial Modification}

The string headed by down below may be modified by another adverb. Instances of far modifying the string are the following: 
(64) Far down below us, out of sight, a scoop burrows through the earth, lifting a single drill at a time.

(65) In distinctive low-wing flight wings are hardly raised above horizontal plane and depressed far down below body at bottom of downstroke.

Another example modified by well is:

(66) Over the years his workings were taken well down below this horizon, raising ore from two shafts, Bonsor East and Bonsor West.

The next is the case of even modifying the string (this example has been sited previously as (8)):

(67) In very open country, the judgement of heights, even down below 200 or 300 feet, is surprisingly difficult.

Examples in 3.3 show that the down below string constitutes some kind of a unit of its own.

\subsection{Discussion}

It has been shown that the down below string has full-fledged syntactic functions of a preposition, derivational uses as a prepositional adverb, and adverbial modifiers which indicates the unity of the string as a complex unit. These facts strongly indicate that the string in question is a complex preposition in present-day English.

\section{Conclusion}

The above examinations of various syntactic characteristics of the down below string have confirmed that the string is a complex preposition. Now there are at least two complex prepositions formed from two particles: down below and up above (which has been confirmed as a complex preposition in Hirao (2014)). This would suggest that forming a complex preposition from two particles is a productive word formation process in English. It might be reminded at this point that English has a number of single word prepositions which, in close examination, are combinations of two particles or a bound-morpheme and a particle: into, onto, upon, within, without, across, around, behind, beside, beneath, underneath. The fact that English has this proportion of single word prepositions formed from two elements within a very closed family of functional items may mean that combining two elements to form a preposition has long been a productive pattern in English.

\section{References}

Crystal, D. (1980). A First Dictionary of Linguistics and Phonetics, London: Andre Deutsch.

Hancil, S. \& Köwnig, E. (eds.) (2014). Grammaticalization - Theory and Data, Amsterdam: John Benjamins.

Hirao, H. (2013). Three Complex Prepositions with And. International Journal of English Linguistics, 3(2), 25-31. http://dx.doi.org/10.5539/ijel.v3n2p25

Hirao, H. (2014). Up above as a complex preposition. English Linguistics Research, 3(1), 12-17. http://dx.doi.org/10.5430/elr.v3n1p12

Hoffmann, S. (2005). Grammaticalization and English Complex Prepositions: A Corpus-based Study, Oxon: Routledge.

Hopper, P. J. \& Traugott, E. C. (1993). Grammaticalization, Cambridge: Cambridge University Press.

Hopper, P. J. \& Traugott, E. C. (2003). Grammaticalization (2 $2^{\text {nd }}$ edn), Cambridge: Cambridge University Press. http://dx.doi.org/10.1017/CBO9781139165525

Leech, G. \& Svartvik, J. (1975). A Communicative Grammar of English, London: Longman.

Leech, G. \& Svartvik, J. (1996). A Communicative Grammar of English $\left(2^{\text {nd }}\right.$ edn), London: Longman.

Leech, G. \& Svartvik, J. (2002). A Communicative Grammar of English ( $3^{\text {rd }}$ edn), London: Pearson.

Quirk, R. et. al. (1972). A Grammar of Contemporary English, London: Longman.

Quirk, R. et. al. (1985). A Comprehensive Grammar of the English Language, London: Longman.

Quirk, R. \& Mulholland, J. (1964). Complex prepositions and related sequences. English Studies (Supplement; Frstschrift for $R$. W. Zandvoort), 45, 64-73. http://dx.doi.org/10.1080/00138386408597188

Rompaey, T van \& Davidse, K. (2014). The different developments of progressive aspect markers be in the middle/midest of and be in the process of V-ing: Mechanisms of change. in Hancil and Köwnig (2014) Grammaticalization - Theory and Data, Amsterdam: John Benjamins, pp. 181-202.

Seppänen, A., Bowen, R. \& Traugott, E. C. (1994). On the So-called Complex Prepositions. Studia Anglica Posnaniensia, 29, 3-29. 